\title{
COMPARATIVE ANALYSIS OF OPC BRANDS COMMONLY USED IN KURDISTAN REGION-IRAQ
}

\author{
Mudhafer H. SELman \\ College of Technical Engineering, Duhok Polytechnic University-Iraq
}

(Accepted for Publication: December 8, 2020)

\begin{abstract}
Nowadays the brand of cement used in construction works is selected mostly on experience, availability, and cost. This study aims to evaluate and compare the chemical and physical properties of five brands of commercial ordinary Portland cement (OPC) available in the Kurdistan region, which are (Mass, Delta, Kar, Mardin, and Şanliurfa). Several tests on each cement brand's sample have been done in the laboratory to analyze their properties according to British Standards (BS). The chemical composition of the cement brands was analyzed by x-ray fluorescence method and the cement tests also include (normal consistency, initial setting time, final setting time, soundness, loss of ignition, fineness, flexural strength, and compressive strength). The effect of chemical composition on the mechanical properties also studied. The results show that all samples have chemical contents within the acceptable limits. Şanliurfa cement has the highest compressive strength at 28 days with $55.4 \mathrm{~N} / \mathrm{mm}^{2}$ and it is about $27.7 \%$ more than

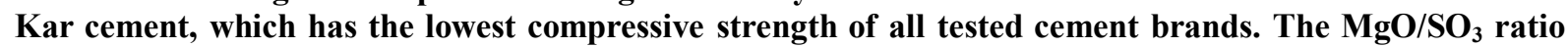
results show that the Şanliurfa cement has the lowest ratio with 0.62 comparing with other cement brands and this influences its compressive strength results. The (Mardin, Mass, Delta, and Kar) cement were found to be classified as $42.5 \mathrm{~N}$ class, these cement brands recommended to be used in bearing concrete structural elements, commercial ready mix concrete plants, and rigid pavement construction work. On the other hand, the study found that Şanliurfa cement classified as $52.5 \mathrm{~N}$ class and it is recommended to use in high strength concrete works.
\end{abstract}

KEYWORDS: Ordinary Portland Cement; Brands of Cement; Chemical Composition; Compressive Strength; Mechanical Properties.

\section{INTRODUCTION}

Portland cement is considered one of the most important construction materials in the world. In the Kurdistan region, there are many brands of cement in the market, both locally manufactured and imported. As is well known that the different types of cement, although they appear relatively similar in chemical composition, differ in physical properties, depending on the raw materials, manufacturing, and the proportions of chemical constituent. Cement is generally chosen based on compressive strength, which is considered one of the most important properties of cement, but this does not diminish the importance of other chemical and physical properties, which must be taken into consideration in choosing the appropriate cement in the various construction works.

Ordinary Portland cement is one of the construction materials of high importance due to the high global consumption of this material. It is made from mixing calcite and clay raw materials and burned to obtain clinker, which is mixed with a proportion of gypsum ranging between $3-6 \%$ of the clinker weight. Then, clinker ground to the required fineness to obtain the Portland cement [1]. Four primary oxides representing Portland cement composition are lime $(\mathrm{CaO})$, silica $\left(\mathrm{SiO}_{2}\right)$, alumina $\left(\mathrm{Al}_{2} \mathrm{O}_{3}\right)$, and ferric oxide $\left(\mathrm{Fe}_{2} \mathrm{O}_{3}\right)$ [2,3]. Chemical components in Portland cement are combined to form different potential compounds. The amounts of these potential compounds are responsible for various physical properties of Portland cement [4]. In Portland, cement four major compounds are tricalcium silicate $\left(\mathrm{C}_{3} \mathrm{~S}\right)$, dicalcium silicate $\left(\mathrm{C}_{2} \mathrm{~S}\right)$, tricalcium aluminate $\left(\mathrm{C}_{3} \mathrm{~A}\right)$, and tetracalcium aluminoferrite $\left(\mathrm{C}_{4} \mathrm{AF}\right)$. The most important compounds are $\mathrm{C}_{3} \mathrm{~S}$ and $\mathrm{C}_{2} \mathrm{~S}$, which are playing a primary role in Portland cement paste strength. $\mathrm{C}_{3} \mathrm{~A}$ and $\mathrm{C}_{4} \mathrm{AF}$ are the lowest compounds in Portland cement, where the 
presence of $\mathrm{C}_{3} \mathrm{~A}$ is considered undesirable in cement while $\mathrm{C}_{4} \mathrm{AF}$ is the least influencing the properties of cement [5].

The increase of $\mathrm{CaO} / \mathrm{SiO}_{2}$ ratio content in cement increases the compressive strength of concrete produced with that cement. [6]. It is well known that the strengths of cement from different localities differ a lot in spite of a high similarity of the contents of alite and other phases. Almost always, such differences are looked upon as results of different concentrations of the minor oxides, especially $\mathrm{SO}_{3}$, alkali oxides, and $\mathrm{MgO}$. The low content of these oxides has a significant influence on the polymorphism of clinker phases, and particularly on alite, the principal hydraulic phase [7].

The relationship between strength and both the chemical composition and clinker morphology of the cement has provided a way of predicting the mechanical performance of cement during and after its hydration, it found that rapidly cooled clinker creates smaller crystals which are more reactive during the manufacturing process [8].

The rapidly cooled clinker would produce concrete that has faster strength development than clinker which was cooled much slower, however over an extended duration the clinkers would produce concrete of similar strength although one of them will get the strength earlier than the other. Clinker strength increases most with increasing $\mathrm{C}_{3} \mathrm{~S}$ proportions and less with $\mathrm{C}_{2} \mathrm{~S}$ proportions. The author also notes that since only two silicates exist in clinker, i.e. $\mathrm{C}_{3} \mathrm{~S}$ and $\mathrm{C}_{2} \mathrm{~S}$, an increase in one led to a decrease in the other, which means that as the effect of the one diminishes, owing to percentage composition, the effect of the other increased. Although $\mathrm{C}_{3} \mathrm{~S}$ is key in the early strength development of cement, an excessive amount can negatively affect cement strength [9].

The principal hydraulic compound of clinker can exist in seven structural modifications i.e. three triclinic, three monoclinic, and one trigonal modification. It also noted that $\mathrm{SO}_{3}$ and $\mathrm{MgO}$ contents had a significant influence on the nature of the modification, where the decrease in the $\mathrm{MgO} / \mathrm{SO}_{3}$ ratio resulting in a modification that increases the compressive strength of the cement [7].

\section{MATERIALS}

Five brands of commercial ordinary Portland cement, which are (Şanliurfa, Mardin, Mass, Delta, and Kar) were used for this work, the samples were all collected from the local market. Société Nouvelle standard sand according to BSEN 196-1 were used for Portland cement mortar prisms. A distilled water was used for this work to prepare a cement paste.

\section{EXPERIMENTAL PROGRAM}

\subsection{Chemical Tests}

\subsubsection{X-ray fluorescence (XRF)}

Using the procedure described in the BS EN 196$2: 2013$, an analysis of the chemical composition of the cement samples was performed by (XRF) method. Cement chemical oxide analysis was done using x-ray fluorescence spectroscopy, as seen in Figure (1). On the other hand, Bogue's equations were used to calculate the percentage of the major constituents in each cement brand.

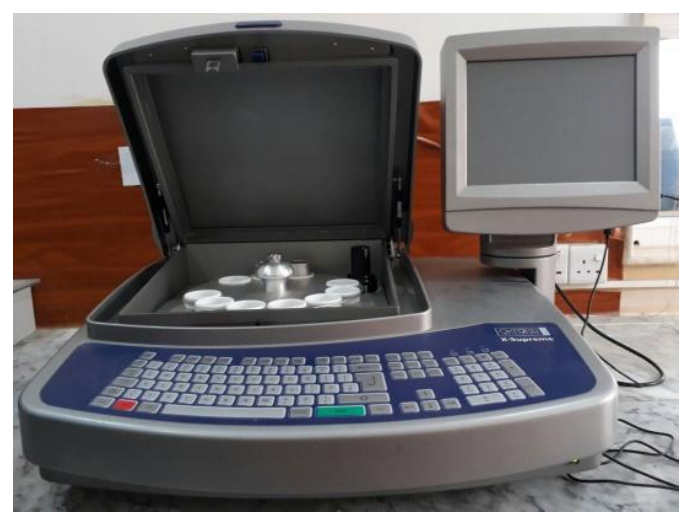

Fig.(1): X- ray equipment 


\subsubsection{Loss on Ignition}

Loss on ignition represents the change in the weight of the cement under the temperature of $(950 \pm 25)^{\circ} \mathrm{C}$. The test was carried out in accordance with BS EN 196-2:2013, using an oven with a temperature of $1000^{\circ} \mathrm{C}$, and using a sensitive balance of 4 decimeters per gram, as shown in the Figure (2).

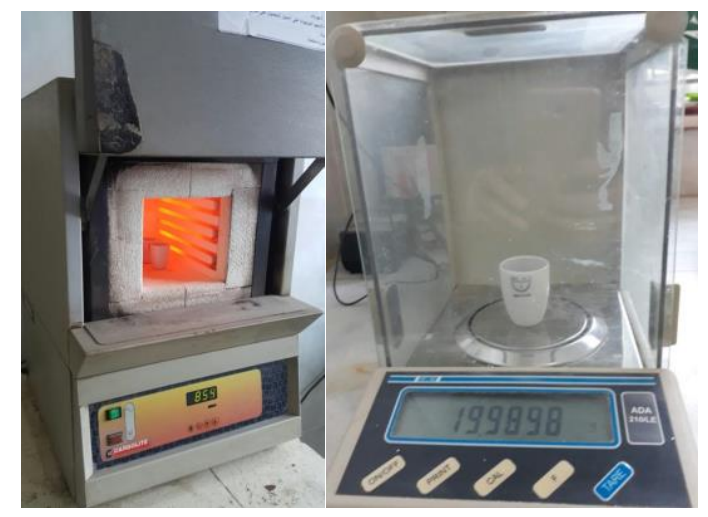

Fig. (2): The oven and Ceramic crucibles on a

\subsubsection{Standard Consistency and Setting Time Tests}

The standard consistency test was performed using $500 \mathrm{~g}$ cement batch with a sufficient amount of water according to BS EN 1963:2016. The initial and final setting was measured also by using the Vicat apparatus.

\subsubsection{Soundness Test}

The soundness of cement determined by the paste prepared for consistency test. Le-Chatelier method (see Figure (4)) was performed a test to assess the durability of cement. The test was done according to BS EN 196-3:2016 standard.

\subsubsection{Compressive and Flexural strength Tests}

In these tests, we prepared the mortar with cement, standard sand, and distilled water. The

\subsection{Physical Tests}

\subsubsection{Fineness Test}

The test was performed using the Blaine apparatus according to the British specifications BS EN 196-6:2010 as shown in Figure (3).

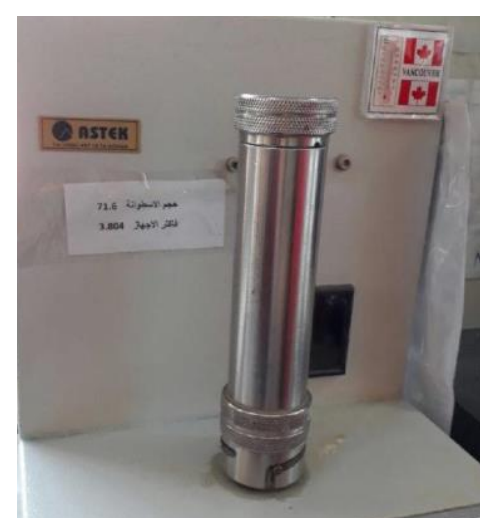

Fig. .(3): Electronic Blaine apparatus

mixtures were cast into $40 \times 40 \times 160 \mathrm{~mm}$ steel prisms and then is compacted in a mold using a jolting apparatus. The compressive and flexural strength was tested at age of (2, 7, and 28 days), the prism specimens were tested by the flexure machine with a loading rate of $(50 \pm 10 \mathrm{~N} / \mathrm{s})$ as shown in Figure (5). The broken prism samples result from the flexural test was used in the compression test, we measured compressive strength for each piece of prisms in the compression machine as shown in Figure (5) with a loading rate of $(2400 \pm 200 \mathrm{~N} / \mathrm{s})$. The flexural and compressive strength tests were carried out in compliance with BS EN 196$1: 2016$. 


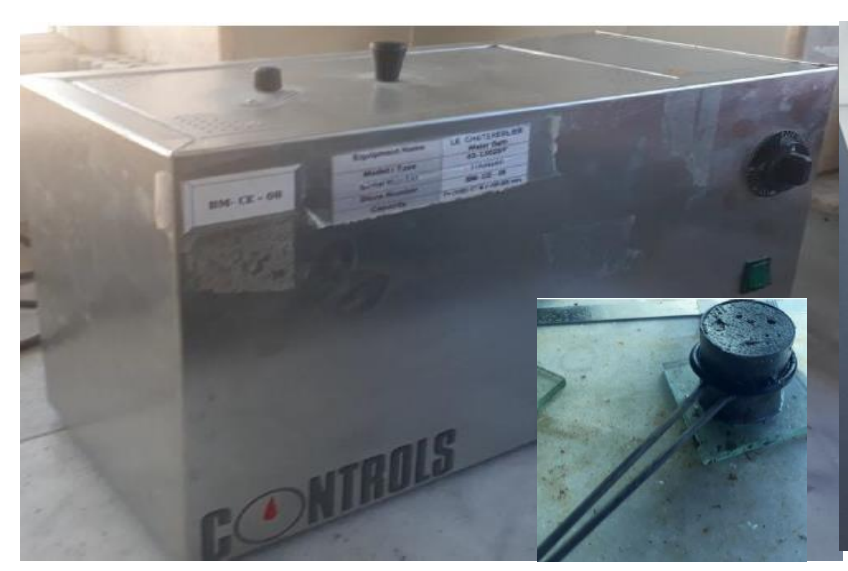

Fig. (4): Le-Chatilier apparatus

\subsection{Chemical Composition:}

4. RESULTS AND DISCUSSION

The oxide composition of the various Portland cement brands considered as determined from the $\mathrm{X}$-ray technique is presented in Table (1). Sulfate content $\left(\mathrm{SO}_{3}\right)$ as

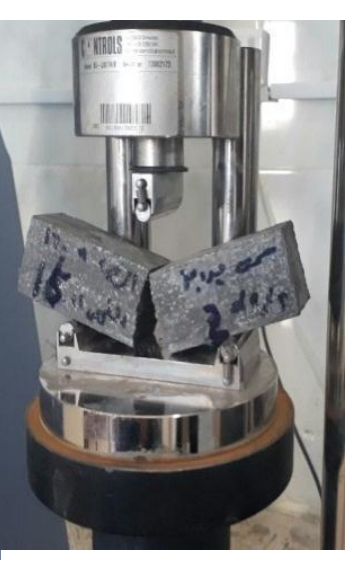

Fig. (5): Samples under flexural and compression machines apparatus

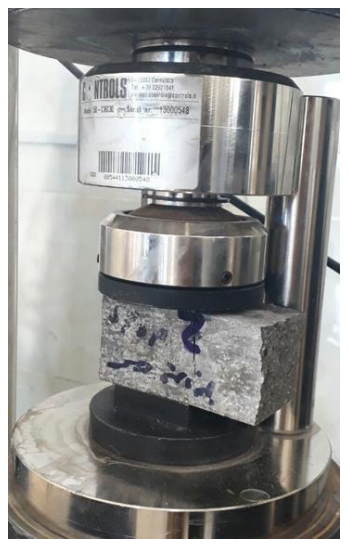

specified in BS EN 197-1 should be less than 3.5 $\%$, all cement brands was within the limit. Sulphur trioxide is known to accelerate the setting time of cement paste and contributing to soundness

[6].

Table. (1): Oxide content of cement samles

\begin{tabular}{lrrrrrrrrrrrr}
\hline $\begin{array}{l}\text { Brand } \\
\text { name }\end{array}$ & $\mathrm{SiO}_{2}$ & $\mathrm{Al}_{2} \mathrm{O}_{3}$ & $\mathrm{Fe}_{2} \mathrm{O}_{3}$ & $\mathrm{CaO}$ & $\mathrm{MgO}$ & $\mathrm{SO}_{3}$ & $\mathrm{Na}_{2} \mathrm{O}$ & $\mathrm{K}_{2} \mathrm{O}$ & $\mathrm{TiO}_{2}$ & $\mathrm{P}_{2} \mathrm{O}_{5}$ & $\mathrm{MnO}$ & $\mathrm{LOI}$ \\
\hline Şanliurf & 20.70 & 5.53 & 3.27 & 63.29 & 1.25 & 2.02 & 0.21 & 0.44 & 0.37 & 0.13 & 0.06 & 4.01 \\
\hline Mardin & 21.55 & 5.23 & 3.83 & 60.54 & 2.59 & 2.02 & 0.22 & 0.80 & 0.31 & 0.06 & 0.06 & 3.70 \\
\hline Mass & 21.27 & 5.27 & 3.20 & 62.40 & 1.61 & 2.01 & 0.24 & 0.52 & 0.26 & 0.05 & 0.08 & 2.55 \\
\hline Delta & 21.15 & 5.23 & 3.49 & 62.26 & 1.63 & 2.05 & 0.25 & 0.51 & 0.27 & 0.05 & 0.10 & 2.48 \\
\hline Kar & 2 & 5. & 3. & 6 & 1. & 1 & 0. & 0 & 0 & 0 & 0. & 5. \\
\hline
\end{tabular}

Lime $(\mathrm{CaO})$ forms nearly two-third of cement. High lime content is associated with early strength whereas, slightly lower content of lime favors ultimate strength which develops gradually over a long period of time [10]. The appropriate proportion of lime content is limited to the low early compressive strength of OPC when the lime content in cement is very low, and to the cement unsoundness when the lime content is too high $[5,10]$. The highest amount of $\mathrm{CaO}$ was in Şanliurfa brand, while the lowest lime content was recorded to Mardin cement brand, as shown in Figure (6).

Silica $\left(\mathrm{SiO}_{2}\right)$ affects the strength of cement due to the formation of $\mathrm{C}_{2} \mathrm{~S}$ and $\mathrm{C}_{3} \mathrm{~S}$, the strength of cement can be attributed to the presence of silica [11]. As shown in Figure (7), Mardin cement has the highest value of $\mathrm{SiO}_{2}$ which is
$21.55 \%$, while Şanliurfa has the lowest $\mathrm{SiO}_{2}$ content which is $20.7 \%$.

According to BS EN197-1:2011, the ordinary Portland cement $\mathrm{CaO} / \mathrm{SiO}_{2}$ ratio contents should not be less than 2. All investigated cement brands were meet the British standard requirement, the $\mathrm{CaO} / \mathrm{SiO}_{2}$ ratio for cement brands, Şanliurfa, Mardin, Mass, Delta, and Kar was $3.05,2.81,2.93,2.94$, and 2.99 respectively, as shown in Figure (8). Also, according to BS EN197-1:2011, the sum of lime $(\mathrm{CaO})$ and silica $\left(\mathrm{SiO}_{2}\right)$ should be not less than $50 \%$, where all cement brands samples used for this research meet this requirement. The sum of $\mathrm{CaO}$ and $\mathrm{SiO}_{2}$ for cement samples Şanliurfa, Mardin, Mass, Delta, and Kar was 83.99, 82.09, 83.67, 83.41, and 83.77 respectively. 


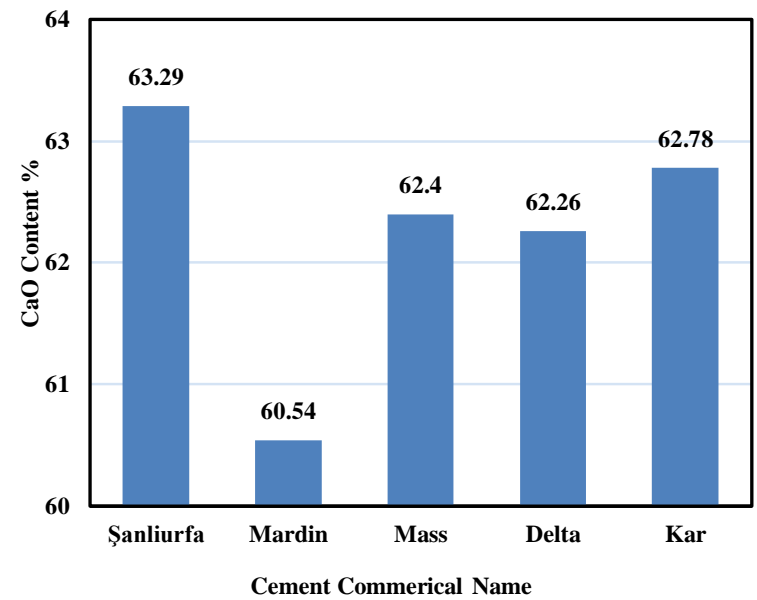

Fig. (6): Lime $(\mathrm{CaO})$ content in cement samples.

The magnesium oxide $(\mathrm{MgO})$ content in ordinary Portland cement should be not more than 5\% due to BS EN197-1:2011, were all cement brands satisfied this limitation, as shown in Figure (9). Increasing $\mathrm{MgO}$ content in cement generally results in a decrease in compressive strength of concrete especially at later ages, also

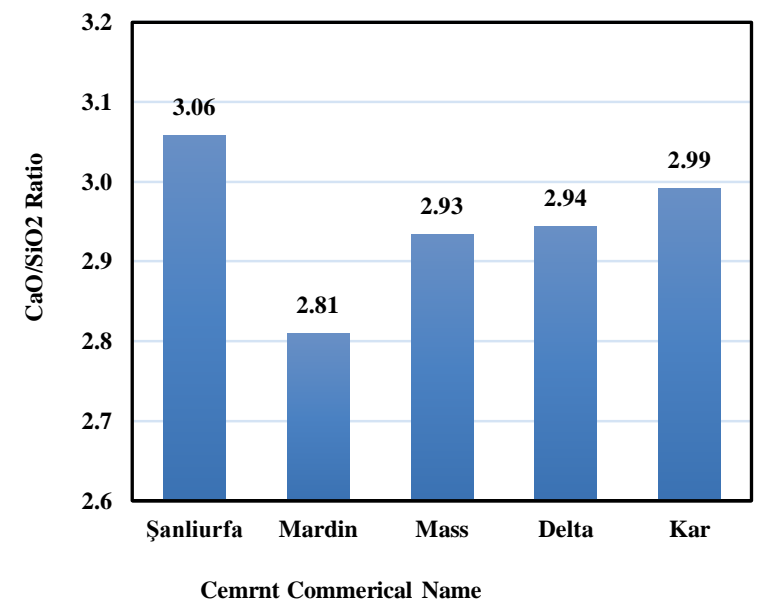

Fig. (8): $\mathrm{CaO} / \mathrm{SiO} 2$ ratio in cement samples

The major constituents of OPC brands were calculated by using the Bogue equation. Table (2) shows the percentages of major chemical components $\left(\mathrm{C}_{3} \mathrm{~S}, \mathrm{C}_{2} \mathrm{~S}, \mathrm{C}_{3} \mathrm{~A}\right.$, and $\left.\mathrm{C}_{4} \mathrm{AF}\right)$ of cement brands, based on the concentrations of the chemical oxides. The comparison of the major constituents for different cement brands can be shown in Figure 10. It can be seen that all

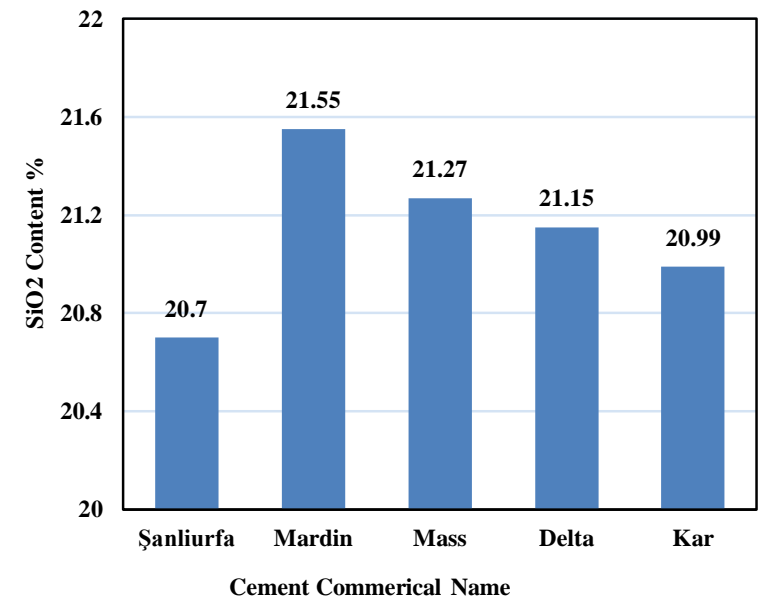

Fig. (7): Silicon dioxide (SiO2) content in cement samples.

increases soundness. Moreover, loss on ignition (LOI) in Portland cement should be less than 5\% due to the BS EN197-1:2011, Figure (10) shows that all cement samples meet the requirement except Kar cement brand were has the highest Loss on ignition with $5.46 \%$.

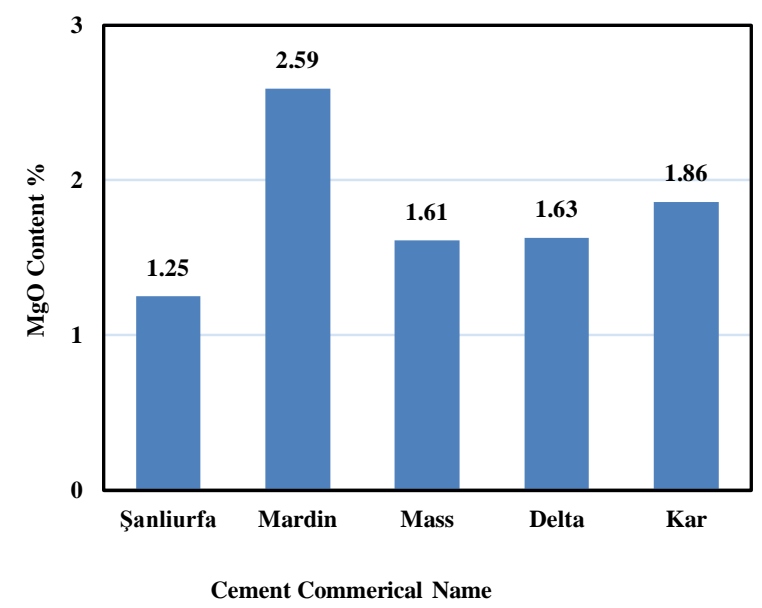

Fig. (9): Magnesium Oxide ( $\mathrm{MgO})$ content in cement samnles

cement samples have high Tricalcium Silicate $\left(\mathrm{C}_{3} \mathrm{~S}\right)$ content compared with other major components, Şanliurfa has the highest $\mathrm{C}_{3} \mathrm{~S}$ percentage and Mardin has the lowest percentage the OPC with relatively high Tricalcium Silicate tend to have a higher compressive 


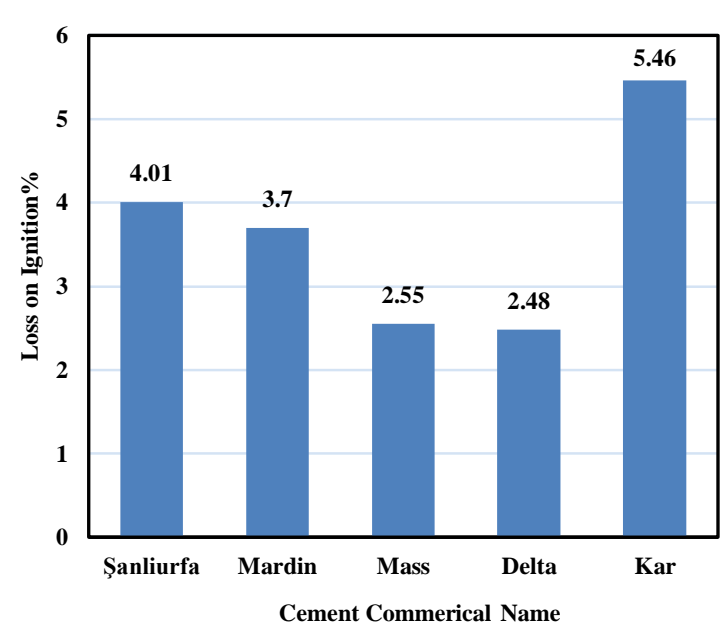

Fig..(9): Loss on ignition of content in cement samples

\subsection{Physical Tests}

Table (3) shows the results of specific gravity, fineness, initial setting, final setting, and soundness tests of Portland cement brands. The finesse of the cement effect directly on compressive strength and rate of hydration,

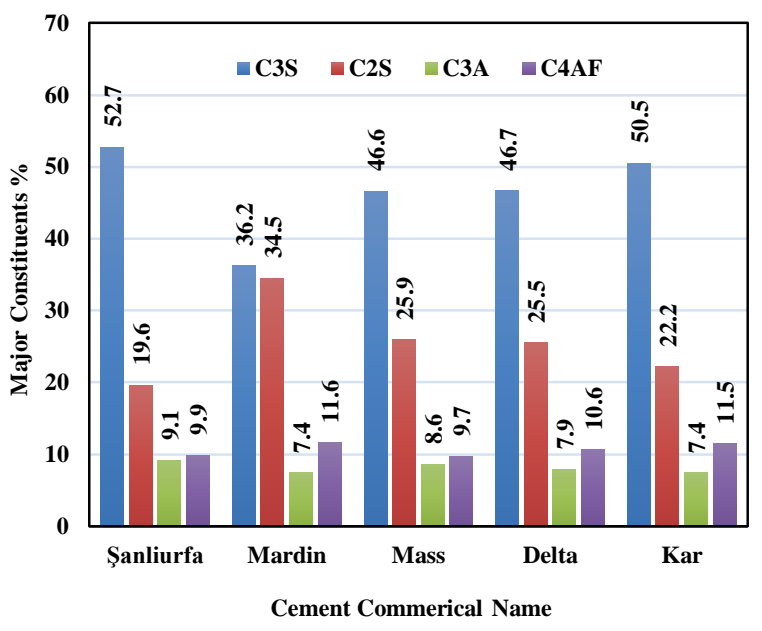

Fig. (10): Major constituents percentage in cement samples

which in turn plays a fundamental role in the early strength development. Kar cement brand has the highest fineness with $433 \mathrm{~m}^{2} / \mathrm{kg}$, while the lowest fineness is $335 \mathrm{~m}^{2} / \mathrm{kg}$ was recorded for the Şanliurfa cement brand, as shown in Figure (11).

Table. (3): Physical test results

\begin{tabular}{|l|l|l|l|l|l|}
\hline $\begin{array}{l}\text { Brand } \\
\text { name }\end{array}$ & $\begin{array}{l}\text { Sp. } \\
\text { Gravity }\end{array}$ & $\begin{array}{l}\text { Fineness } \\
\left(\mathbf{m}^{\mathbf{2}} / \mathbf{k g}\right)\end{array}$ & $\begin{array}{l}\text { Initial } \\
\text { Setting } \\
\text { Time } \\
(\mathbf{m i n})\end{array}$ & $\begin{array}{c}\text { Final } \\
\text { Setting } \\
\text { Time(min) }\end{array}$ & $\begin{array}{l}\text { Soundness } \\
(\mathbf{m m})\end{array}$ \\
\hline Şanliurfa & 3.01 & 335 & 157 & 270 & 2 \\
\hline Mardin & 3.03 & 403 & 180 & 230 & 3 \\
\hline Mass & 3.12 & 348 & 126 & 225 & 2 \\
\hline Delta & 3.18 & 366 & 139 & 255 & 1 \\
\hline Kar & 3.17 & 443 & 143 & 240 & 3 \\
\hline
\end{tabular}

The initial setting time of the five samples lies in the range of 126-180 minutes while the final setting time occurs between 225-270 minutes. According to BS EN 197-1:2011 standards requirements, initial setting time should be higher than or equal to, 75 minutes for $32.5 \mathrm{~N}$ strength class, 60 minutes for $42.5 \mathrm{~N}$ strength class, and 45 minutes for $52.5 \mathrm{~N}$ strength class. The five samples of cement are within limits stated by the standard. However, no limitation is specified for Final setting time in BS EN 197-1:2011 standard. Setting time difference may be as a result of the selective hydration of $\mathrm{C}_{3} \mathrm{~A}$ and $\mathrm{C}_{3} \mathrm{~S}$ and is accompanied by temperature rises in the cement paste according to properties and applications in concrete [12].
Table (3) shows the soundness results, according to BS EN 197-1:2011 the expansion should not be more than $10 \mathrm{~mm}$, the highest value is detected to Mardin and Kar cement with $3 \mathrm{~mm}$, while Delta cement has the lowest expansion value with $1 \mathrm{~mm}$, all cement samples are within limit stated by the standard. Higher expansion reading of Mardin and Kar cement brands over the other brands may be associated with high $\mathrm{MgO}$ content $(2.59,1.86) \%$, respectively. This results show that the soundness of cement samples was more related to the $\mathrm{MgO}$ content.

Compressive and flexural strength of mortar samples (prisms) tested on 2, 7, and 28 days, the results were listed in Table (4). According to EN 197-1:2011 the ordinary Portland cement

Corresponding author: College of Technical Engineering, Duhok Polytechnic University, Kurdistan Region, Iraq 
classify into three strength classes $(32.5 \mathrm{~N}$, $42.5 \mathrm{~N}$, and $52.5 \mathrm{~N}$ ) due to its compressive strength in 2 and 28 days. The results of compressive strength show that all the cement brands classified as $42.5 \mathrm{~N}$ strength class, except the Şanliurfa cement brand classified as $52.5 \mathrm{~N}$ strength

class.

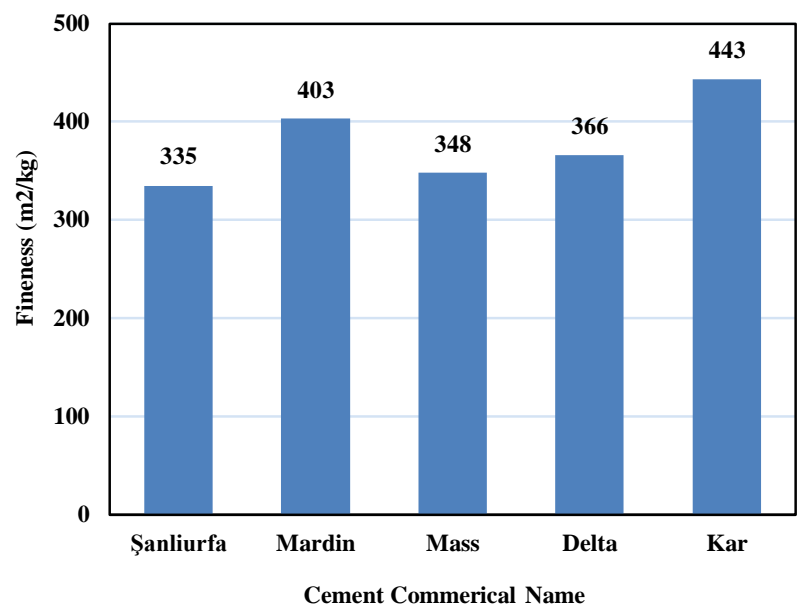

Fig. (11): Fineness of cement samples

The early compressive and flexural strength results show that the Mardin cement brand has the highest strength with respect to other cement brands sample, as shown in Figure (12) and (13). Also, the compressive strength results show the Kar cement brand has the lowest early age strength in spite of the relatively high fineness $\left(443 \mathrm{~m}^{2} / \mathrm{kg}\right)$, this may due to the high percentage of loss on ignition $(5.46 \%)$, were increasing in loss of ignition affect the cement strength especially at early ages. The Şanliurfa cement brand has the highest compressive and flexural strength at 28 days with $55.4 \mathrm{MPa}$ and $9.64 \mathrm{MPa}$ respectively, this may due to relatively high $\left(\mathrm{CaO} / \mathrm{SiO}_{2}\right)$ ratio with respect to other samples of cement. This, in turn, led to an increase in the percentage of $\mathrm{C}_{3} \mathrm{~S}$ content (52.7\%), which is the highest among cement samples. However, the $\mathrm{MgO} / \mathrm{SO}_{3}$ contents had a significant influence on the compressive strength. The decrease in the $\mathrm{MgO} / \mathrm{SO}_{3}$ ratio resulting in a modification that increases the compressive strength of the cement [7], the results show the $\mathrm{MgO} / \mathrm{SO}_{3}$ ratio was $0.62,1.28,0.8,0.79$ and 0.99 for Şanliurfa, Mardin, Mas, Delta, and Kar respectively. The results showed that the lower $\mathrm{MgO} / \mathrm{SO}_{3}$ ratio was the Şanliurfa cement with the highest compressive strength at 28 days, on the other hand, the same behavior recorded for Mardin and Kar cement brands, as they were own the higher $\mathrm{MgO} / \mathrm{SO}_{3}$ ratio and the lowest results of compressive strength at 28 days.

Table.(4): Compressive and flexural strength of all cement samples

\begin{tabular}{lllllll}
\hline \multirow{2}{*}{$\begin{array}{l}\text { Brand's } \\
\text { name }\end{array}$} & \multicolumn{3}{c}{ Compressive strength } & \multicolumn{3}{c}{ Flexural strength (MPa) } \\
\cline { 2 - 7 } & 2 days & 7 days & 28 days & 2 days & 7 days & 28 \\
\hline Şanliurfa & 22.3 & 48.0 & 55.4 & 5.06 & 9.44 & 9.64 \\
\hline Mardin & 26.2 & 42.51 & 47.6 & 6.25 & 7.38 & 8.26 \\
\hline Mass & 20.6 & 35.9 & 47.6 & 4.52 & 6.48 & 8.06 \\
\hline Delta & 23.2 & 37.8 & 50.4 & 5.25 & 6.63 & 7.84 \\
\hline Kar & 19.6 & 31.9 & 43.4 & 5.36 & 5.77 & 7.85 \\
\hline
\end{tabular}




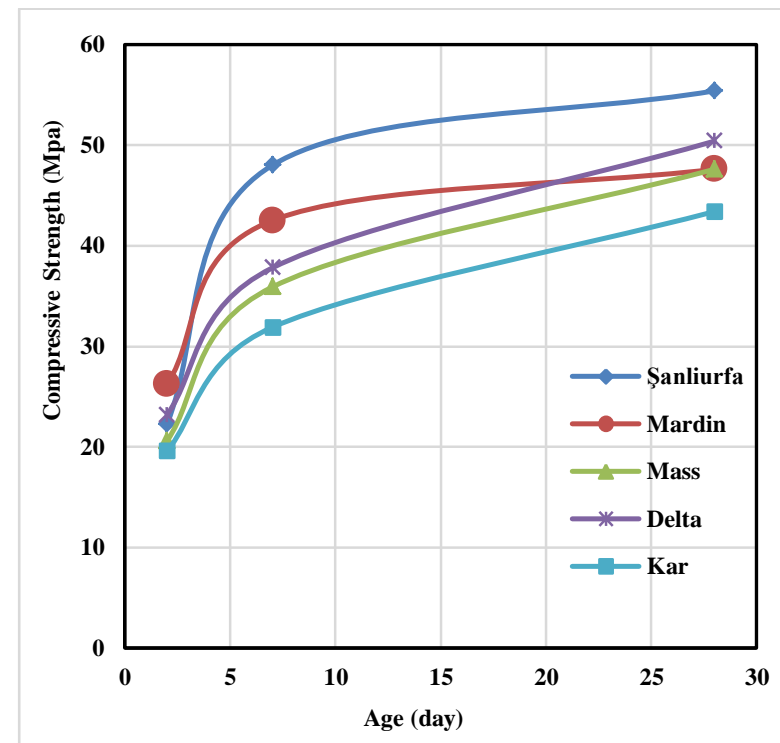

Figure.12: Compressive strength of cement samples

\section{CONCLUSION}

1. The results of the chemical analysis of the cement samples showed that they are all within the limits of British standards. Şanliurfa cement brand was found to have the highest content of lime $(\mathrm{CaO})$, and as a result, it has the highest content of Tricalcium Silicate $\left(\mathrm{C}_{3} \mathrm{~S}\right)$, which plays an important role in the development of cement strength.

2. All cement samples satisfied the British standard in setting time tests, while the results of the fineness test of the cement brands ranged between (335-443) $\mathrm{m}^{2} / \mathrm{kg}$.

3 . The results of the soundness test showed that cement brands comply with the standard limits, and the results also showed the effect of $\mathrm{MgO}$ content on soundness results, as the increase in $\mathrm{MgO}$ content increases the expansion of cement. 4. Results of compressive strength for cement samples were classified Şanliurfa cement brand as $(52.5 \mathrm{~N})$ strength class, while the rest of the cement brands were classified as $(42.5 \mathrm{~N})$ strength class according to English specifications.

5. The $\mathrm{MgO} / \mathrm{SO}_{3}$ ratio content in cement samples affects the 28 days compressive strength, where the compressive strength was higher for cement samples with low $\mathrm{MgO} / \mathrm{SO}_{3}$ ratio content.

6 . All cement brands recommended being used in bearing concrete structural elements, commercial ready mix concrete plants, and rigid

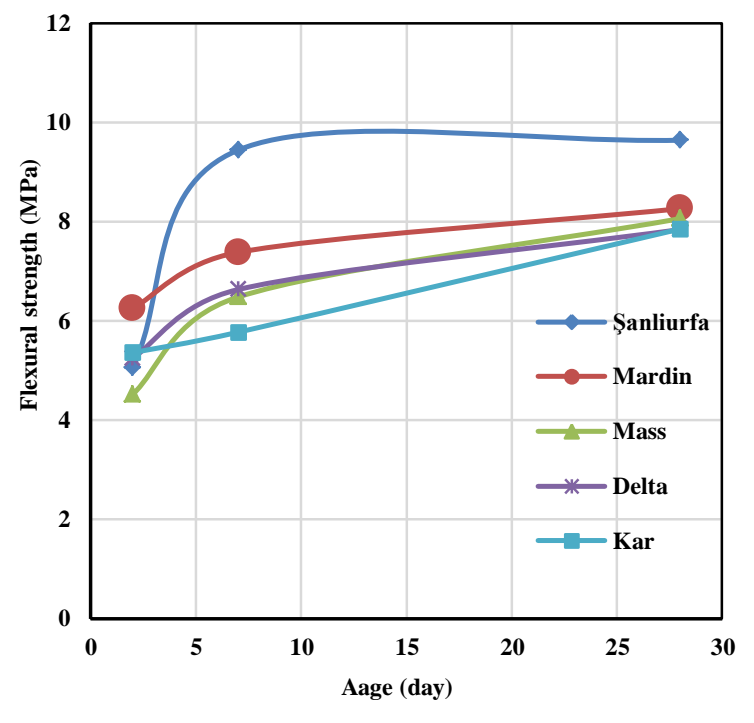

Figure.13: Flexural strength of cement samples

pavement construction work. Also, the Şanliurfa cement brand is recommended to be used in high strength concrete works.

\section{REFERENCES}

Y. Baran, H.S. Gokçe, M. Durmaz. Physical and mechanical properties of cement containing regional hazelnut shell ash wastes. Journal of Clear Production. 259, 120969, 2020. https://doi.org/10.1016/j.jclepro.2020.120965

Bogue R.H. The Chemistry of Portland Cement, 2nd Edition. Reinhold Publishing Corporation, 1955.

M. S. Ali, I. A. Khan, and M. I. Hossain. Chemical Analysis of Ordinary Portland Cement of Bangladesh. Chemical Engineering Research Bulletin. 12, 2008: 7 -10.

Mark Bediako, Eric Opoku Amankwah. Analysis of Chemical Composition of Portland Cement in Ghana: A Key to Understand the Behavior of Cement. Advances in Materials Science and Engineering. 2015, 349401, 2015. https://doi.org/10.1155/2015/349401

Neville A.M. Concrete Technology. 5th ed. Pearson Education Limited, 2011.

Arimanwa M. C, Onwuka D. O, Arimanwa J. I. Effect of Chemical Composition of Ordinary Portland cement on the Compressive Strength 
of Concrete. International Refereed Journal of Engineering and Science (IRJES). 5, 3, 2016:20-31.

T. Stanek, P. Sulovsky. The Influence of the Alite Polymorphism on The Strength of the Portland Cement. Cement and Concrete Research. 32, 7, 2002: 1169-1175. https://doi.org/10.1016/S0008-8846(02)00756$\underline{1}$

St John, D, Poole, AW and Sims, I. Concrete Petrography. 4th edition. Elsevier, 1998.

Svinning, K, Hoskuldson, $\mathrm{A}$ and Justnes, $\mathrm{H}$. Prediction of potential compressive strength of Portland clinker from its mineralogy. Cement and concrete composites. 32, 4, 2010: 300311. https://doi.org/10.1016/j.cemconcomp.2009.12 .004

Duda W. H. Cement Data Book. Vol. 1. Berlin: Bauverlag GmbH, 1988.

Shrikant Jahagirdar, Vinayak Patki, Shrinivas Metan. Evaluation of Physical and Chemical Properties of OPC and PPC Cement. International Journal of Recent Technology and Engineering (IJRTE). 8, 2S11, 2019: 840845.

https://doi.org/10.35940/ijrte.B1138.0982S111 $\underline{9}$

V.S. Ramachandran, V.M.Malhotra, C, Jolicoeur and N. Spiratos. Superplasticizer: Properties and applications in concrete. Materials Technology Laboratory CANMET, Ottawa.1998. 